Огляди літератури, оригінальні дослідження, погляд на проблему, випадок з практики, короткі повідомлення УДК 616.34-007.43-089.844+616.366-89.87]-089.819

DOI 10.11603/1811-2471.2020.v.i4.11757

\title{
ОЦІНКА РЕЗУЛЬТАТІВ СИМУЛЬТАННИХ ЛАПАРОСКОПІЧНИХ АЛОГЕРНІОПЛАСТИКИ ТА ХОЛЕЦИСТЕКТОМІї
}

\author{
ФМ. М. Галей², І. Я. Дзюбановський ${ }^{1}$, І. П. Марчук² \\ Тернопільський національний медичний університет імені І. Я. Горбачевського МОЗ України \\ КП «Волинська обласна клінічна лікарня»²
}

РЕзЮМЕ. Поширеність калькульозного холециститу та пахової грижі досягає значних показників. Жовчнокам'яна хвороба вражає до 20 \% дорослого населення світу, а пахова грижа виникає протягом життя у 30 \% населення. Поєднання цих патологій не $\epsilon$ рідкістю, отже методи паралельного лікування $є$ актуальними.

Мета - дослідити наслідки використання розробленої техніки симультанних лапароскопічних операцій. Оцінити результати лікування жовчнокам'яної хвороби та пахової грижі й їх поєднання. Проаналізувати і порівняти основні показники ефективності та безпеки власної техніки з класичними техніками холецистектомії й алогерніопластики.

Матеріал і методи. 32013 по 2019 рік проліковано 190 пацієнтів із поєднаною жовчнокам'яною хворобою та паховою грижею, з них 19 з двосторонньою. Операції виконували з використанням власної техніки симультанних операцій (група 1). Також проліковано 312 пацієнтів із лише ЖКХ з використанням стандартної «французької техніки» (група 2) та 237 пацієнтів із лише паховою грижею, з них 33 з двосторонньою, з використанням стандартної трансабдомінальної преперитонеальної техніки (група 3). Оцінку здійснювали шляхом аналізу і зіставлення показників терміну лікування, тривалості операції, концентрації креатиніну сироватки крові, глікемії, артеріального тиску. Використовували статистичні методи Шапіро - Уілка, критерії Манна - Уітні чи U-критерій.

Результати. Тривалість операції склала $(58,24 \pm 5,74)$ хв у першій групі проти $(41,8 \pm 4,66)$ хв у другій та $(39,62 \pm 5,13)$ хв у третій та не перевищувала 2-х годин у жодній з груп; концентрація креатиніну сироватки крові не перевищувала допустимі 2 мг/дл у жодному з випадків та відрізнялась незначуще ( $p=0,937 / p=0,922)$, нормалізувалась у період 6-12 год; глікемія також не мала відмінностей між групами та поверталась до норми у термін відновлення перорального живлення ( $p=0,822 / p=0,954)$; АТ утримувався у межах нормотонії, різниця між інтраопераційними показниками в обох групах була несуттєвою ( $p=0,912 / p=0,874)$; тривалість стаціонарного перебування не різнилась між групами ( $p=0,784 / p=0,861)$ і складала 3,55 дня для першої, 3,51 дня для другої та 3,43 дня для третьої груп.

Висновки. Техніка, розроблена на базі ВІМДл ВОКЛ, не поступається за показниками ефективності та безпеки «французькій» техніці холецистектомії та дозволяє виконувати симультанне операційне лікування холециститу та пахової грижі (включаючи двосторонню) одномоментно. Використання цієї техніки є виправданим та доцільним.

КлючовІ СловА: лапароскопія; симультанні операції; жовчнокам'яна хвороба; пахова грижа.

Вступ. Хірургічні патології, на жаль, не $\epsilon$ рідкісними у сучасному суспільстві. Жовчнокам'яна хвороба займає одне з провідних місць у структурі захворюваності на хірургічні хвороби. Пахові грижі трапляються не рідше. Зрозуміло, що частим $є$ поєднання таких хвороб. Це створює підґрунтя для попиту на паралельне лікування поєднання цих двох захворювань. Зважаючи на те, що основним і обов'язковим етапом лікування холецистолітіазу та пахової грижі є операційний, необхідність у техніці симультанного лікування цих патологій $є$ високою.

Жовчнокам'яна хвороба (ЖKX) займає провідне місце у структурі хірургічної захворюваності, адже зустрічається щонайменше у 20 \% населення [1]. Майже завжди захворювання починається безсимптомно та тривало має торпідний перебіг. Щорічно від 1 \% до 4 \% таких хворих починають страждати від загострень чи ускладнень хвороби, і майже завжди захворювання перебігає за типом жовчної коліки чи механічної жовтя- ниці, рідше - біліарного панкреатиту [1]. Варто зважати також на летальність через ЖКХ, адже внаслідок прямих ускладнень цього захворювання помирає близько 100000 людей щороку [2]. Близько третини населення протягом життя страждатиме від пахової грижі (ПК), з них 27 \% чоловіки і 3 \% - жінки [3]. Ускладнення пахової грижі спричиняють до 60000 смертей щороку [4]. Частим (до 12 \%) є поєднання цих захворювань [5]. Спільним для усіх груп таких пацієнтів $\epsilon$ необхідність операційного лікування, особливо зважаючи на високий рівень ускладнень та не нульову смертність, а також взаємозв'язок між цими показниками та тривалістю і стадією хвороби $[6,7]$.

Зволікання із хірургічним лікуванням $\epsilon$ невиправданим, адже будь-яке загострення ЖКХ може спричинити такі грізні ускладнення як жовтяниця чи холангіт, а операції, виконані у період загострення, мають більший показник тривалості, ускладнень та ятрогенних ушкоджень жовчного міхура та сусідніх органів [8]. Пахова грижа ж може 
Огляди літератури, оригінальні дослідження, погляд на проблему, випадок з практики, короткі повідомлення ускладнитись защемленням органів черевної порожнини, що вимагатиме розширення операції та збільшить ризик ускладнень, а сповільнення кровотоку в органах, що потрапили в грижу, різко збільшує ризики тромбоемболічних ускладнень та смерті від серцево-судинних подій [9].

Зважаючи на можливість використання малоінвазивних методів хірургії у поєднанні із сучасною стратегією ERAS, що гарантують безпечну операцію, швидке відновлення, мінімальні ризики, лапароскопічне операційне лікування $є$ методом вибору [10]. У випадку ж з поєднаної патології найдоцільніше використовувати техніку симультанних лапароскопічних операційних втручань, через їх визнану ефективність у плані зменшення частоти й тривалості госпіталізацій, внутрішньогоспітальних ускладнень та економічної доцільності [11]. щоб уникнути втрати ергономічних показників під час операції, як надзвичайно важливих при оцінці техніки [12], і встановлення додаткових портів, що збільшує травматизацію і ризик, розроблено техніку виконання симультанних лапароскопічних операцій при поєднанні ЖКХ та ПК.

Будь-яка операція спричиняє пошкодження тканин, яке викликає запалення та стимулює ноцицептивні шляхи, що призводить до стресу (основна роль у стрес-відповіді належить інтерлейкіну-6), організм вивільняє стрес-гормони, зокрема адре-

нокортикотропний гормон (АКТГ), альдостерон, кортизол, глюкагон, адреналін [13]. Але з часом цей захисний механізм набуває деструктивного характеру, розвивається стрес-діабет через контрінсулярний ефект гормонів та медіаторів запалення, що вважають провідною причиною післяопераційних ускладнень [14]. Корекція цих показників і зменшення травматизації та часу операції знижує рівень хірургічної стрес-відповіді та допомагає запобігти ускладненням при одночасному пришвидшенні видужання [10].

Матеріал і методи дослідження. Після ретроспективного аналізу історій хвороби пацієнтів відділення інвазивних методів діагностики та лікування Волинської обласної клінічної лікарні (ВІМДЛ ВОКЛ), пролікованих у період з 2013 по 2019 рік, було відібрано 739 історій хвороб, з яких сформовано три групи: 190 симультанних лапароскопічних операційних втручань з приводу ЖКХ та ПК, виконаних за власною розробленою технікою, з яких 19 з приводу двосторонньої ПК - група 1; 312 лапароскопічнох операцій, виконаних 3 приводу ЖКХ за звичайною "французькою» технікою - група 2; 237 лапароскопічних операцій виконаних з приводу ПК за звичайною трансабдомінальною преперитонеальною технікою (ТАРP), з яких 33 з приводу двосторонньої пахової грижі група 3.

Таблиця 1. Характер лапароскопічних операційних втручань

\begin{tabular}{|c|c|c|c|}
\hline Назва операційного втручання & Група & К-ть номінальна & Відсоток \\
\hline ЛХЕ+ТАРP & 1 & 190 & 25.71 \\
\hline ЛХЕ+ТАРP+ТАРP & 1 & 19 & 2.57 \\
\hline ЛХЕ & 2 & 312 & 42.22 \\
\hline TAPP & 3 & 237 & 32.07 \\
\hline TAPP+TAPP & 3 & 33 & 4.47 \\
\hline \multicolumn{2}{|l|}{ Загалом } & 739 & 100 \\
\hline
\end{tabular}

Формування груп здійснювали за нозологічними формами та ознакою коморбідності. Техніку, розроблену на базі ВІМДЛ ВОКЛ для симультанних операцій, використовували у групі 1 (рис. 1), у групах 2 та 3 використовували стандартні техніки, описані раніше нашими колегами $[15,16]$.

Перед операцією хворі проходили стандартне обстеження та передопераційну підготовку, регламентовану інструкціями [10]. Для об'єктивізації та переведення у числову площину показників загального стану пацієнтів та їх операційного ризику використовували шкалу P-POSSUM [17]. Стрес під час операції контролювали шляхом визначення його впливу на рівень артеріального тиску (АТ) (як показник порушення регуляції судиноруховим центром) та глікемію (як маркер стрес-діабету через ви- кид контрінсулярних гормонів), що $є$ опосередкованими, але інформативними показниками, які можливо оцінювати оперативно під час хірургічного втручання. Також після операції визначали креатинін сироватки крові, для оцінки активності секреції надниркових залоз і як предиктор зростання ризиків ниркових та серцевих ускладнень [10].

Оцінка готовності до виписування проводилася з використанням шкали післяопераційної готовності до виписування PT-RHDS (більше відомої як READI) з числовим вираженням для об'єктивності [18]. Згідно з рекомендаціями розробників шкали READI, задовільним вважають показник вище 7 балів, хорошим - вище $9[19,20]$.

Структура пацієнтів продемонстрована у таблиці 2. 


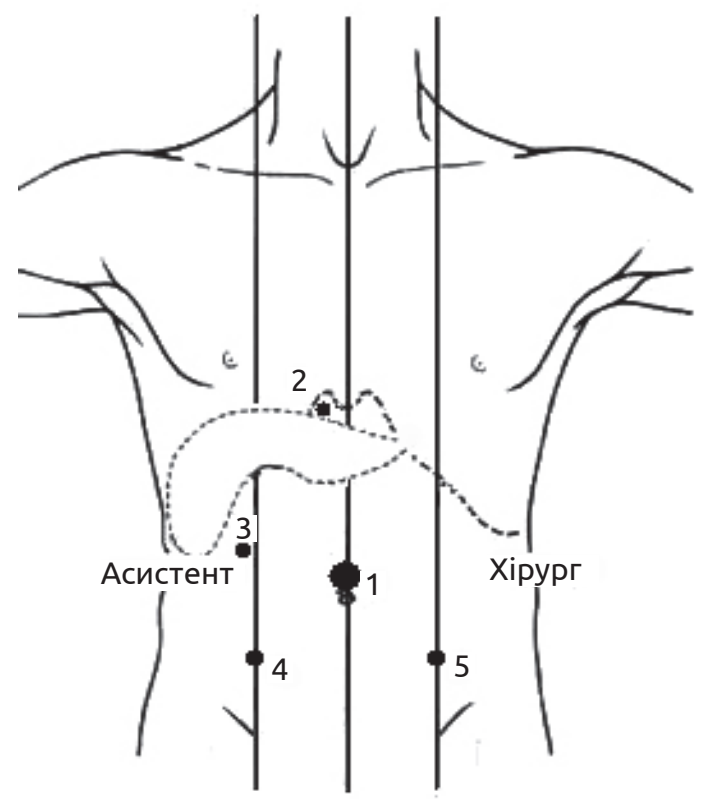

Рис. 1. Схема встановлення портів для виконання симультанних лапароскопічних операцій з приводу ЖКХ та ПК: 1 - 10 мм порт для лапароскопа та виведення препарату в завершальній фазі операції; 2 - 10 мм порт для основного інструменту хірурга та для лапароскопа для візуального контролю в завершальні фазі операції; 3 - 5 мм порт для допоміжного інструменту хірурга під час холецистектомії та інструменту асистента під час алогерніопластики; 4 - 5 мм порт для інструменту асистента під час холецистектомії та інструменту хірурга під час алогерніопластики. Відстань між портом 1 (проекція білої лінії живота) та зоною прикладання хірургічної дії - 1/2 довжини тіла лапароскопа (330 мм), кут між інструментами хірурга -60-90, а кут введення портів-45 по відношенню до площини стола.

Таблиця 2. Характеристика пацієнтів, яким виконані операційні втручання, за віком і статтю

\begin{tabular}{|l|c|c|c|c|c|c|c|c|}
\hline \multirow{2}{*}{$\begin{array}{c}\text { Назва операційних } \\
\text { втручань }\end{array}$} & \multicolumn{9}{c|}{ Вік, роки } \\
\cline { 2 - 10 } & \multicolumn{2}{|c|}{$25-44$} & \multicolumn{2}{c|}{$45-60$} & \multicolumn{2}{c|}{$60-75$} & \multicolumn{2}{c|}{$75-90$} \\
\cline { 2 - 10 } & чоловіки & жінки & чоловіки & жінки & чоловіки & жінки & чоловіки & жінки \\
\hline ЛХЕ+ТАРP & 38 & 4 & 41 & 3 & 54 & 6 & 20 & 5 \\
\hline ЛХЕ+ТАРP+ТАРP & 4 & 0 & 8 & 1 & 2 & 0 & 3 & 1 \\
\hline ЛХЕ & 18 & 39 & 27 & 89 & 31 & 72 & 22 & 14 \\
\hline TАРP & 41 & 11 & 69 & 14 & 36 & 9 & 12 & 12 \\
\hline TАРP+ТАРP & 6 & 1 & 14 & 2 & 4 & 0 & 4 & 2 \\
\hline
\end{tabular}

Власне техніку оцінювали шляхом аналізу числових показників часу операційного втручання у кожній з груп (вимірювання у хвилинах, дані отримано зі стандартної форми № 003-3/о загального протоколу знеболювання), та тривалості післяопераційного перебування на стаціонарному лікуванні та реабілітації (вимірювання у добах, дані отримано зі стандартної карти стаціонарного хворого, форма № 003/о). Отриману інформацію внесено до бази даних та проаналізовано за допомогою програми «Statistica®» версії 12.6 від StatSoft" USA. Опис кількісних ознак на основі критерію Шапіро - Уілка, з визначенням середнього арифметичного (M) і стандартного відхилення (S). Порівняння груп проводили з використанням критерію Мана - Уітні чи U-критерію. Критичний рівень значущості р у всіх розрахунках 0,05.
Результати й обговорення. За шкалою Р-

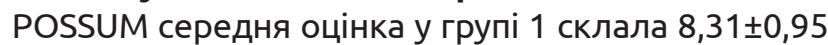

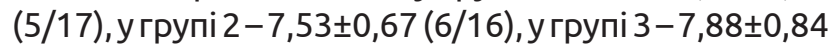
(6/18).

У групі 1 тривалість операції була більшою, порівняно з групами 2 та 3. Середня тривалість операційного втручання (час інтубація - екстубація) склала $(58,24 \pm 5,74)$ хв $(41-75$ хв) у першій групі, $(41,8 \pm 4,66)$ хв (27-61 хв) у другій групі, та $(39,62 \pm 5,13)$ хв (24-61 хв) у третій групі (рис. 2).

Концентрація креатиніну сироватки крові, яку визначали у період реабілітації для оцінки стрес-відповіді та ризику серцево-судинних і ниркових ускладнень (одразу після екстубації та через 2, 6, 12 годин після операції, у період найбільшої інформативності), наведена на рисунку 3. 


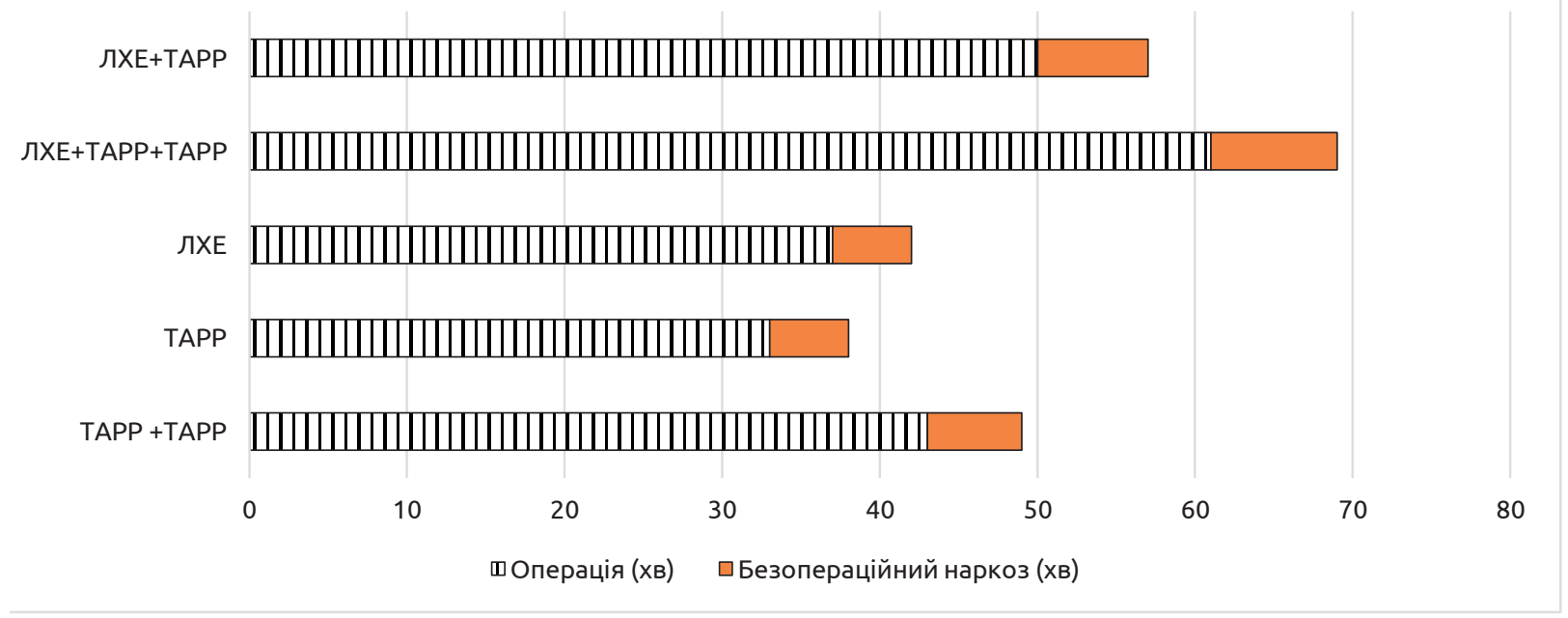

Рис. 2. Середня тривалість операції у групах.

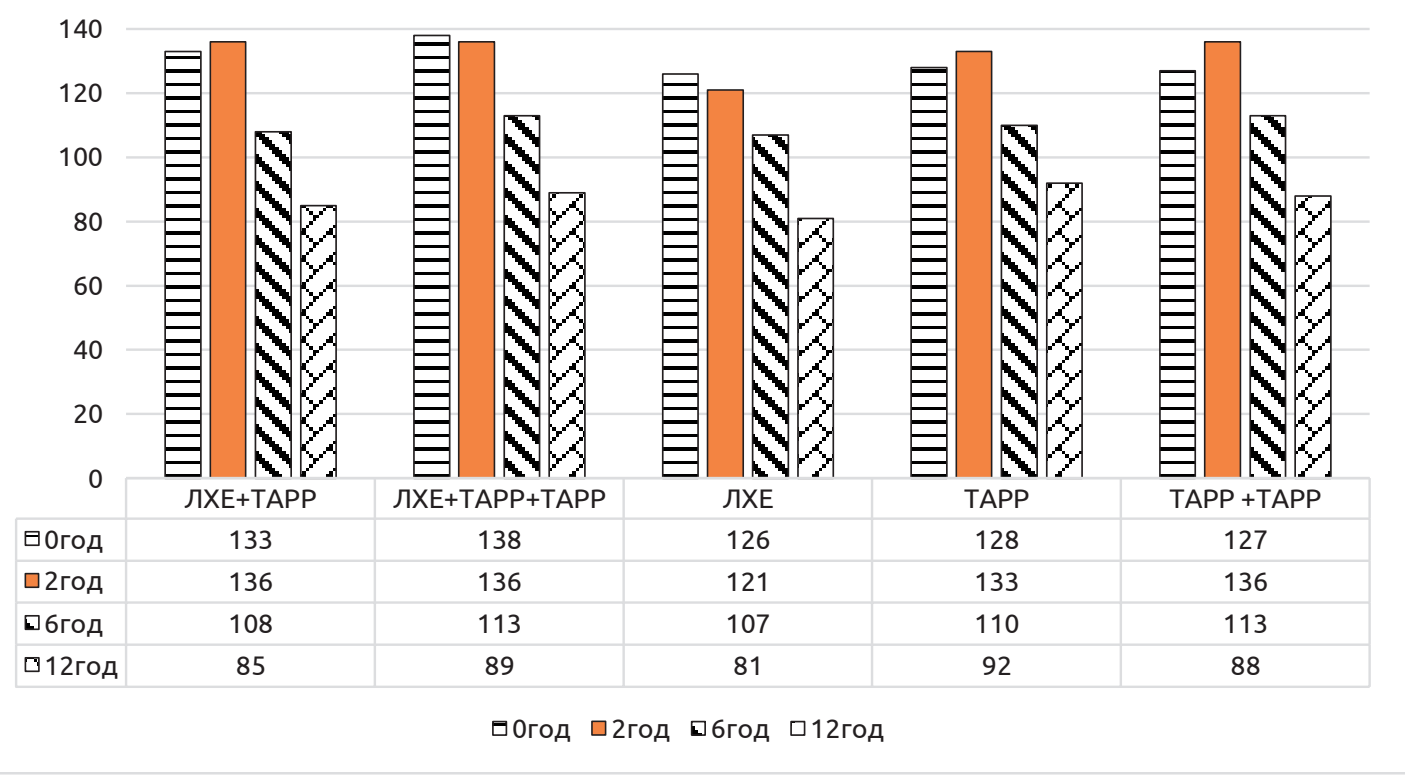

Рис. 3. Концентрація креатиніну сироватки крові у групах.

Глікемію вимірювали через 30 хв після розрізу, а також одразу після екстубації та у післяопераційному періоді через 2, 6 та 12 годин. Результати, отримані під час дослідження, наведені на рисунку 4.

Контроль артеріального тиску проводили в автоматичному режимі кожні 5 хв під час операції за допомогою монітора пацієнта Dräger ${ }^{\mathrm{TM}}$ Vista $120 ®$. Дані, отримані в результаті вимірювань, заносили у журнал (стандартна форма №003-3/о загального протоколу знеболювання). Артеріальна гіпотензія - це зниження середнього АТ на $30 \%$ від початкового, чи зниження більш як до 80 мм рт. ст. у систолічній фазі, або девіація сегмента ST на ЕКГ [7]. АТ зберігався у нормотонії і при необ- хідності корегувався однаково у всіх випадках, згідно з інструкціями, а саме: збільшення темпу інфузії кристалоїдів, збільшення кількості колоїдів чи додавання пресорів при неефективності перших двох пунктів (рис. 5).

Готовність пацієнта до виписування зі стаціонару оцінювали щоранку з 2-го дня після операції. Результати оцінювання за шкалою READI наведені на рисунках 6, 7. Показання до виписування визначали об'єктивно та шляхом використання опитувальника форми PT-RHDS з числовим вираженням для об'єктивності. У всіх випадках керувались інструкціями ERAS (оновленні 2019 року), а також рішеннями колегій дослідників (ISS 2007, JAMA 2005), що досі $\epsilon$ чинними, котрі наголошують на 
Огляди літератури, оригінальні дослідження, погляд на проблему, випадок з практики, короткі повідомлення

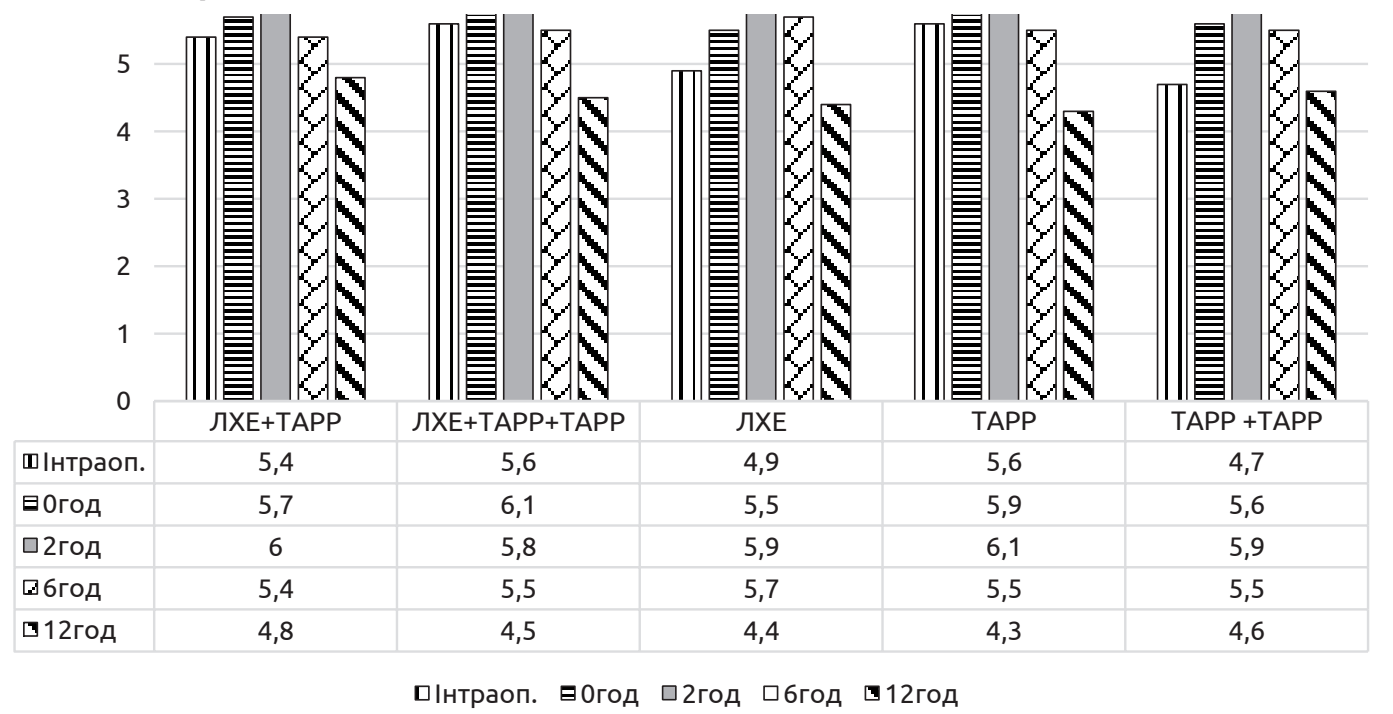

Рис. 4. Глікемія у групах.

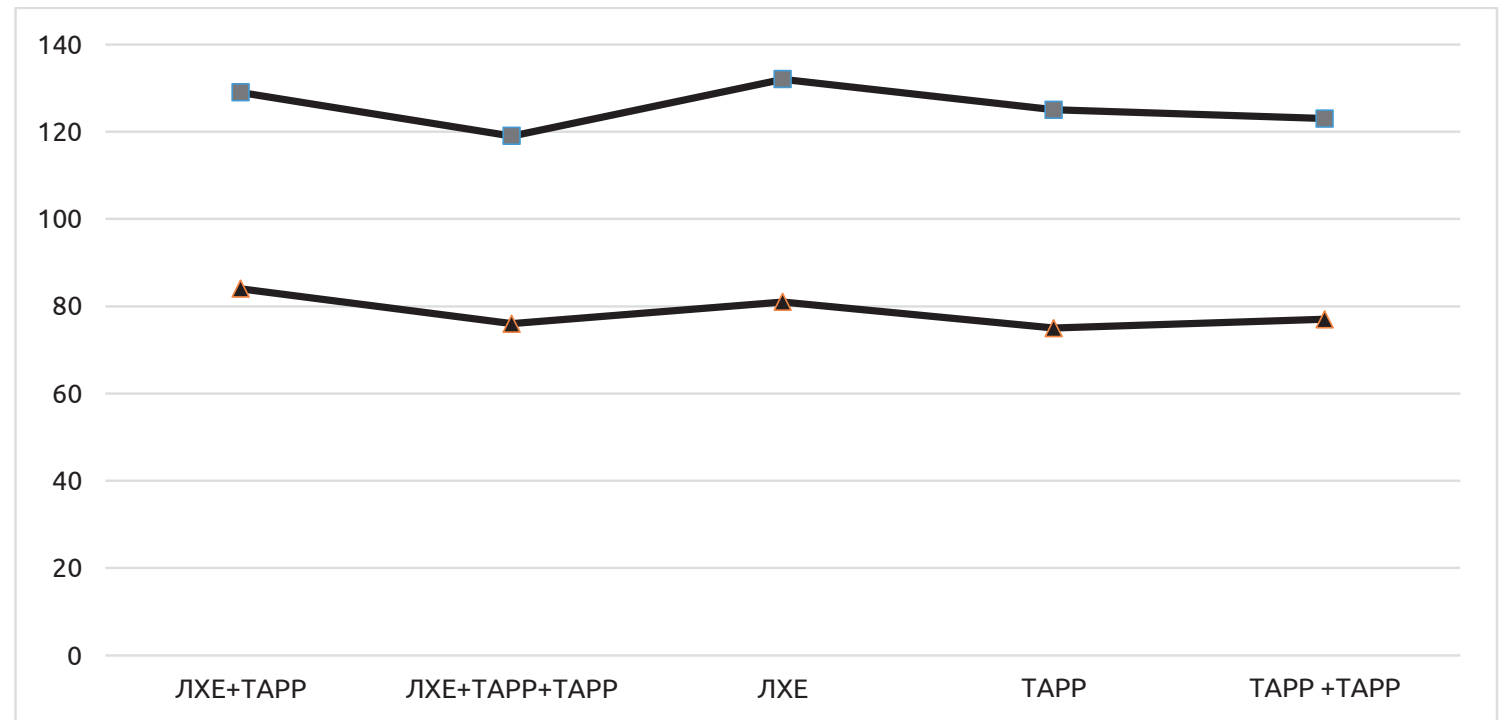

Рис. 5. Середній артеріальний тиск під час операції у групах.

необхідності мінімізації тривалості перебування пацієнтів у стаціонарі для зниження кількості пов'язаних із цим ускладнень та збільшення ефективності й доцільності лікування.

Різниця між групами за шкалою P-POSSUM не перевищувала $10 \%$, статистичної значущості не виявлено $(p=0,697 / p=0,864)$, отже, групи були однорідні за ознакою хірургічного ризику, а у структурі пацієнтів не виявлено перекосу в ту чи іншу вікову групу, у порівнянні між групами, що підтверджує однорідність пацієнтів та репрезентативність досліджень.

У всіх трьох групах тривалість операції вкладається у час безпечного «контрольованого» наркозу, тобто до 2-х годин. У групі симультанних хо- лецистектомії та ТАРP (включаючи двосторонню) не зареєстровано виходу за вказані межі, що не призводило до збільшення ризиків [21]. Зростання часу операції у групі симультанних операцій за власною технікою складає до 2-х годин, отже, не збільшується ризик пульмонологічних ускладнень за шкалою ARISCAT [22]. У досліджуваній групі час на 30 \% більший за час операції у групі 2 та на 35 \% більший за час у групі 3, та цей час однаково складає до 19 хв, що незіставно із тривалістю однієї лише холецистектомії чи алогерніопластики, як у нашому досліді, так і у дослідах наших колег [23-25]. Зауважимо, що ми та наші колеги наголошують на тому, що сам операційний прийом може тривати менше чи зіставно із 
Огляди літератури, оригінальні дослідження, погляд на проблему, випадок з практики, короткі повідомлення

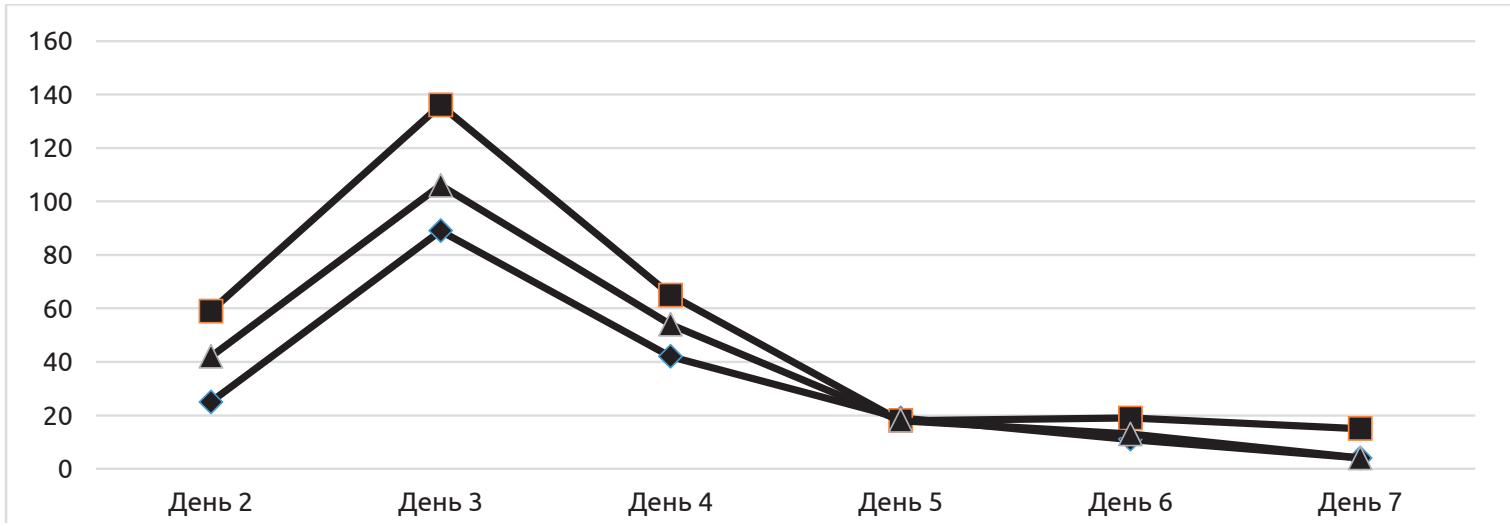

Рис. 6. День готовності до виписування пацієнтів трьох груп. Номінально. Лінійно. У відсотковому співвідношенні та ж інформація наведена для наочності.

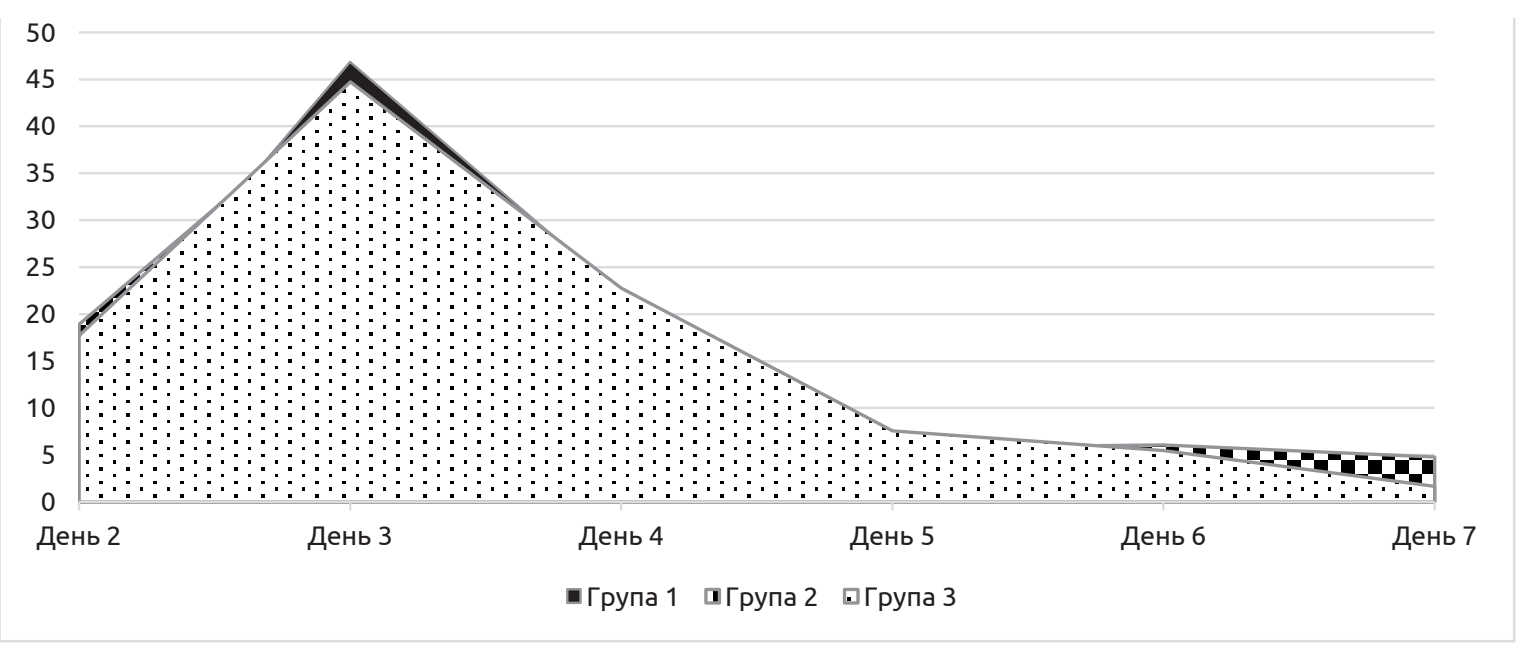

Рис. 7. День готовності до виписування пацієнтів трьох груп. У відсотках. Секторно з накладанням.

тривалістю формування доступу та зашиванням, а за умови наявності спайкового процесу (як-то під час повторної операції, чого дозволяє уникнути симультанна техніка) час може зростати суттєво [26]. Треба усвідомлювати важливість комплексного підходу і паралельного лікування для зменшення часу стаціонарного перебування та кількості шпиталізацій, а отже й витрат, що досягається завдяки симультанному підходу, що звільняє пацієнта від потреби в повторній шпиталізації чи продовженні лікування кожної нозологічної форми окремо [5]. Також зрозуміло, що зникають ризики шпиталізації пацієнта під час загострення чи з ускладненнями [8].

Концентрація креатиніну сироватки крові не перевищувала 2 мг/дл (мг/дл × 88,4=ммоль/л, тобто 177 ммоль/л) у жодному з випадків, що не збільшувало ризик серцево-судинних подій, як ускладнень операцій за шкалою Lee. Нормалізація показника відбулась до кінця першої доби після операції, починаючи з 6-ти годин після операції. Така дина- міка збігається із середнім часом відновлення пероральної гідратації й живлення та вертикалізації пацієнтів (6-12 годин), як того і вимагає інструкція пришвидшеного відновлення після операцій [10]. Власна техніка симультанних лапароскопічних операцій не не відрізняється за цим параметром від стандартної техніки холецистектомії $(p=0,937)$ чи алогерніопластики ( $p=0,922)$.

Використання інструкцій по контролю глікемії та пероральному насиченню вуглеводами у передопераційному періоді допомогло запобігти розвитку суб'єктивного дискомфорту та неспокою у пацієнтів, також рідко виникали такі явища як нудота та блювання, слабкість через 2 години після операції. Об'єктивно не виявлено зростання розвитку стрес-діабету у відповідь на ушкодження тканин унаслідок симультанних операцій, а показники глікемії не виходили за критичні межі у всіх етапах і не вимагали корекції інсуліном чи розчинами глюкози. Стрес-діабет згідно з чинними інструкціями оцінюється як один з про- 
Огляди літератури, оригінальні дослідження, погляд на проблему, випадок з практики, короткі повідомлення відних факторів розвитку інфекційних ускладнень, у тому числі післяопераційних ран, а також сповільнення загоєння, появи слабкості та гіпотензії після операційних втручань, тому його відсутність $є$ показником ефективності та безпеки підходу [10]. Після порівняння трьох груп різниці за показником глікемії не виявлено, а симультанна техніка відрізнялась від стандартних статистично незначуще ( $p=0,822 / p=0,954)$. У всіх групах відбувалось відновлення пероральної гідратації та живлення до 12 годин, глікемія нормалізувалась до кінця першої доби. Варто зазначити, що при наявності сильної нудоти та в разі відмови пацієнта від перорального живлення використовували розчини для післяопераційного перорального живлення (у нашому випадку Nutricomp ${ }^{\circledR}$ ВВгаun ${ }^{\mathrm{TM}}$ ).

Різниця між середнім систолічним та середнім діастолічним артеріальним тиском протягом операції між групами була відсутня ( $p=0,912$ / $\mathrm{p}=0,874)$. Розроблена техніка симультанного лікування ЖКХ та ПК не призводить до зростання ризиків розвитку інтраопераційної гіпотензії як предиктора серцево-судинного ризику.

У групі однієї лише холецистектомії дещо більший показник ранньої виписки (2 доби), хоча і зростає показник виписки через 7 діб, порівняно із досліджуваною симультанною технікою. Середні показники складали 3,55 дня для першої групи, 3.51 дня для другої групи та 3,43 дня для третьої. Після виконання статистичного аналізу не виявлено різниці між групами симультанних та стандартних лапароскопічних операцій $(p=0,784 / p=0,861)$. Виконання симультанних лапароскопічних втручань за розробленою технікою не призводить до збільшення тривалості госпіталізації.

\section{ЛІТЕРАТУРА}

1. 2016 WSES guidelines on acute calculous cholecystitis / L. Ansaloni, M. Pisano, F. Coccolini [et al.] // World. J. Emerg. Surg. - 2016. - Vol. 11. - P. 25.

2. Global, regional, and national incidence, prevalence, and years lived with disability for 301 acute and chronic diseases and injuries in 188 countries, 1990-2013: A systematic analysis for the Global Burden of Disease Study // Lancet. - 2015. - Vol. 386 (9995). - P. 743-800.

3. Fitzgibbons R. J. Jr. Clinical practice. Groin hernias in adults / R. J. Fitzgibbons Jr, R. A. Forse // N. Engl. J. Med. - 2015. - Vol. 372 (8). - P. 756-763.

4. Global, regional, and national life expectancy, allcause mortality, and cause-specific mortality for 249 causes of death, 1980-2015: A systematic analysis for the Global Burden of Disease Study 2015 // Lancet. - 2016. Vol. 388 (10053). - P. 1459-1544.

5. Comparison of comorbidity scores in predicting surgical outcomes / H. B. Mehta, F. Deepak, D. Adhikari [et al.] // Med. Care. - 2016. - Vol. 54 (2). - P. 180-187.

6. Demehri F. R. Evidence-based management of common gallstone-related emergencies /F. R. Demehri, H. B. Alam // J. Intensive Care Med. - 2016. - Vol. 31 (1). - P. 3-13.

7. Evidence-based clinical practice guidelines for cholelithiasis 2016 / S. Tazuma, M. Unno, Y. Igarashi [et al.] // J. Gastroenterol. - 2017. - Vol. 52 (3). - P. 276-300.

8. Severity of acute cholecystitis and risk of iatrogenic bile duct injury during cholecystectomy, a population-based case-control study / B. Törnqvist, A. Waage, Z. Zheng [et al.] // World J. Surg. - 2016. - Vol. 40 (5). P. 1060-1067.

9. European Hernia Society guidelines on the treatment of inguinal hernia in adult patients / M. P. Simons, 
Огляди літератури, оригінальні дослідження, погляд на Vol. 13 (4). - P. 343-403.

10. Guidelines for perioperative care for liver surgery: enhanced recovery after surgery (ERAS) society recommendations / E. Melloul, M. Hübner, M. Scott [et al.] // World J. Surg. - 2016. - Vol. 40 (10). - P. 2425-2440.

11. Kurygin A. A. Social and economic aspects of simultaneous operations on abdominal organs / A. A. Kurygin, V. V. Semenov // Vestn. Khir. Im. I. I. Grek. - 2016. Vol. 175 (3). - P. 100-105.

12. Supe A. N. Ergonomics in laparoscopic surgery / A. N. Supe, G. V. Kulkarni, P. A. Supe // J. Minim. Access Surg. - 2010. - Vol. 6 (2). - P. 31-36.

13. Nimmo S. M. Enhanced recovery after surgery: Pain management / S. M. Nimmo, I. Foo, H. M. Paterson // J. Surg. Oncol. - 2017. - Vol. 116 (5). - P. 583-591.

14. Gillis C. Promoting perioperative metabolic and nutritional care / C. Gillis, F. Carli // Anesthesiol. - 2015. Vol. 123 (6). - P. 1455-1472.

15. Kim S. S. Laparoscopic cholecystectomy / S. S. Kim, T. R. Donahue // JAMA. - 2018. - Vol. 319 (17). - P. 1834.

16. Surgical technique and outcomes of transabdominal preperitoneal inguinal hernia repair after radical prostatectomy: dissection between the transversalis fascia and superficial layers of preperitoneal fascia / M. Ohuchi, M. Fukunaga, K. Nagakari [et al.] // Hernia. - 2019. - Vol. 23 (1). P. 167-174.

17. The applicability of POSSUM and P-POSSUM scores as predictors of morbidity and mortality in colorectal surgery / M. E. Carvalho-E-Carvalho, F. L. DE-Queiroz, B. X. Мartins-DA-Costa [etal.]//Rev.Col.Bras.Cir.-2018.-Vol.45(1).P. e1347.

18. Weiss M. E. Perceived readiness for hospital discharge in adult medical-surgical patients / M. E. Weiss, L. B. Piacentine, L. Lokken [et al.] //Clin. Nurs. Spec. -2007.Vol. 21 (1). - P. 31-42.

19. Nurhayati N. Surgical patients experiences of readiness for hospital discharge and perceived quality of discharge teaching in acute care hospitals / N. Nurhayati, P. Songwathana, R. Vachprasit // J. Clin. Nurs. - 2019. Vol. 28. - P. 1728-1736.

20. Weiss M. E. Validation of patient and nurse short forms of the readiness for hospital discharge scale and their relationship to return to the hospital / M. E. Weiss, L. L. Costa, O. Yakusheva // Health Serv. Res. - 2014. Vol. 49 (1). - P. 304-317.

21. Sridharan K. Comparison of fentanyl, remifentnil, sufentanil and alfentanil in combination with propofol for general anesthesia: a systematic review and meta-analysis of randomized controlled trials / K. Sridharan, G. Sivaramakrishnan // Curr. Clin. Pharmacol. - 2019. - Vol. 14 (2). P. 116-124.

22. Kara S. Predicting pulmonary complications following upper and lower abdominal surgery: asa vs. ARISCAT risk index / S. Kara, E. Küpeli, H. Yılmaz // Turk. J. Anaesthesiol. Reanim. - 2020. - Vol. 48 (2). - P. 96-101.

23. Impact of risk factors for prolonged operative time in laparoscopic cholecystectomy / M. Zdichavsky, Y. A. Bashin, G. Blumenstock [et al.] // Eur. J. Gastroenterol. Hepatol. - 2012. - Vol. 24 (9). - P. 1033-1038.

24. Impact of seniority on operative time and shortterm outcome in laparoscopic cholecystectomy: Experience of an academic Surgical Department in a developing country / A. Souadka, M. S. Naya, B. Serji [et al.] // J. Minim. Access Surg. - 2017. - Vol. 13 (2). - P. 131-134.

25. The safety and feasibility of the single-port laparoscopic transabdominal preperitoneal inguinal hernia repair through retropubic radical prostatectomy scar, prospective, case series / J. H. Chung, T. H. Kim, K. Lee [et al.] // J. Laparoendosc. Adv. Surg. Tech. A. - 2018. - Vol. 28 (12 Part A). - P. 1458-1462.

26. Rami Reddy S. R. A systematic review of the clinical presentation, diagnosis, and treatment of small bowel obstruction / S. R. Rami Reddy, M. S. Cappell // Curr. Gastroenterol. Rep. - 2017. - Vol. 19 (6). - P. 28.

\section{REFERENCES}

1. Ansaloni, L., Pisano, M., Coccolini, F., Peitzmann, A.B., Fingerhut, A., Catena, F., ..., \& Moore, E.E. (2016). 2016 WSES guidelines on acute calculous cholecystitis. World. J. Emerg. Surg., 11, 25. DOI: 10.1186/s13017-016-0082-5.

2. (2015). Global, regional, and national incidence, prevalence, and years lived with disability for 301 acute and chronic diseases and injuries in 188 countries, 1990-2013: a systematic analysis for the Global Burden of Disease Study 2013. Lancet, 386 (9995), 743-800. DOI: 10.1016/S01406736(15)60692-4.

3. Fitzgibbons, R.J.Jr., \& Forse, R.A. (2015). Clinical practice. Groin hernias in adults. N. Engl. J. Med., 372 (8), 756-763. DOI: 10.1056/NEJMcp1404068.

4. (2016). Global, regional, and national life expectancy, all-cause mortality, and cause-specific mortality for
249 causes of death, 1980-2015: a systematic analysis for the Global Burden of Disease Study 2015. Lancet, 388 (10053), 1459-1544. DOI: 10.1016/S0140-6736(16)31012-1.

5. Mehta, H.B., Deepak, F., Adhikari, D., Tamirisa, N.P., Sieloff, E., Williams, T.P., ..., \& Riall, T.S. (2016). Comparison of comorbidity scores in predicting surgical outcomes. Med. Care., 54 (2), 180-187. DOI: 10.1097/ MLR.0000000000000465.

6. Demehri, F.R., \& Alam, H.B. (2016). Evidencebased management of common gallstone-related emergencies. J. Intensive Care Med., 31 (1), 3-13. DOI: $10.1177 / 0885066614554192$.

7. Tazuma, S., Unno, M., Igarashi, Y., Inui, K., Uchiyama, K., Kai, M., ..., \& Shimosegawa, T. (2017). Evidence-based clinical practice guidelines for cholelithiasis 2016. J. Gastro- 
Огляди літератури, оригінальні дослідження, погляд на проблему, випадок з практики, короткі повідомлення enterol., 52 (3), 276-300. DOI: 10.1007/s00535-016-1289-7.

8. Törnqvist, B., Waage, A., Zheng, Z., Ye, W., \& Nilsson, M. (2016). Severity of acute cholecystitis and risk of iatrogenic bile duct injury during cholecystectomy, a population-based case-control study. World J. Surg., 40 (5), 10601067. DOI: 10.1007/s00268-015-3365-1.

9. Simons, M.P., Aufenacker, T., Bay-Nielsen, M., Bouillot, J.L., Campanelli, G., Conze, J., ..., \& Miserez, M. (2009). European Hernia Society guidelines on the treatment of inguinal hernia in adult patients. Hernia, 13 (4), 343-403. DOI: 10.1007/s10029-009-0529-7.

10. Melloul, E., Hübner, M., Scott, M., Snowden, C., Prentis, J., Dejong, C. H., ..., \& Demartines, N. (2016). Guidelines for perioperative care for liver surgery: enhanced recovery after surgery (ERAS) society recommendations. World J. Surg., 40 (10), 2425-2440. DOI: https://doi. org/10.1007/s00268-016-3700-1.

11. Kurygin, A.A., \& Semenov, V.V. (2016). Social and economic aspects of simultaneous operations on abdominal organs. Vestn. Khir. Im. I. I. Grek., 175 (3), 100-105.

12. Supe, A.N., Kulkarni, G.V., \& Supe, P.A. (2010). Ergonomics in laparoscopic surgery. J. Minim. Access Surg., 6 (2), 31-36. DOI: 10.4103/0972-9941.65161.

13. Nimmo, S.M., Foo, I., \& Paterson, H.M. (2017). Enhanced recovery after surgery: Pain management. J. Surg. Oncol., 116 (5), 583-591. DOI: https://doi.org/10.1002/ jso. 24814

14. Gillis, C., \& Carli, F. (2015). Promoting perioperative metabolic and nutritional care. Anesthesiol., 123 (6), 14551472. DOI: https://doi.org/10.1097/ALN.0000000000000795.

15. Kim, S.S., \& Donahue, T.R. (2018). Laparoscopic cholecystectomy. JAMA, 319 (17), 1834. DOI: https://doi. org/10.1001/jama.2018.3438.

16. Ohuchi, M., Fukunaga, M., Nagakari, K., Azuma, D., Kohama, S., Nomoto, J., \& Sakamoto, K. (2019). Surgical technique and outcomes of transabdominal preperitoneal inguinal hernia repair after radical prostatectomy: dissection between the transversalis fascia and superficial layers of preperitoneal fascia. Hernia, 23 (1), 167-174. DOI: https://doi.org/10.1007/s10029-018-1800-6.

17. Carvalho-E-Carvalho, M.E., DE-Queiroz, F.L., Martins-DA-Costa, B.X., Werneck-Côrtes, M.G., \& Pires-Rodrigues, V. (2018). The applicability of POSSUM and P-POSSUM scores as predictors of morbidity and mortality in colorectal surgery. Rev. Col. Bras. Cir., 45 (1), e1347. DOI: https://doi. org/10.1590/0100-6991e-20181347.

18. Weiss, M.E., Piacentine, L.B., Lokken, L., Ancona, J., Archer, J., Gresser, S., ..., \& Vega-Stromberg, T. (2007).

Perceived readiness for hospital discharge in adult medical-surgical patients. Clin. Nurs. Spec., 21 (1), 31-42. DOI: https://doi.org/10.1097/00002800-200701000-00008.

19. Nurhayati, N., Songwathana, P., \& Vachprasit, R. (2019). Surgical patients' experiences of readiness for hospital discharge and perceived quality of discharge teaching in acute care hospitals. J. Clin. Nurs., 28 (9-10), 17281736. DOI: https://doi.org/10.1111/jocn.14764.

20. Weiss, M.E., Costa, L.L., Yakusheva, O., \& Bobay, K.L. (2014). Validation of patient and nurse short forms of the readiness for hospital discharge scale and their relationship to return to the hospital. Health Serv. Res., 49 (1), 304-317. DOI: https://doi.org/10.1111/1475-6773.12092.

21. Sridharan, K., \& Sivaramakrishnan, G. (2019). Comparison of fentanyl, remifentanil, sufentanil and alfentanil in combination with propofol for general anesthesia: A systematic review and meta-analysis of randomized controlled trials. Curr. Clin. Pharmacol., 14 (2), 116-124. DOI: https://doi.org/10.2174/1567201816666190313160438.

22. Kara, S., Küpeli, E., Yılmaz, H., \& Yabanoğlu, H. (2020). Predicting pulmonary complications following upper and lower abdominal surgery: ASA vs. ARISCAT risk index. Turk. J. Anaesthesiol. Reanim., 48 (2), 96-101. DOI: https://doi.org/10.5152/TJAR.2019.28158.

23. Zdichavsky, M., Bashin, Y.A., Blumenstock, G., Zieker, D., Meile, T., \& Königsrainer, A. (2012). Impact of risk factors for prolonged operative time in laparoscopic cholecystectomy. Eur. J. Gastroenterol. Hepatol., 24 (9), 1033-1038. DOI: https://doi.org/10.1097/MEG.0b013e328354ad6e.

24. Souadka, A., Naya, M.S., Serji, B., El Malki, H.O. Mohsine, R., Ifrine, L., Belkouchi, A., \& Benkabbou, A. (2017). Impact of seniority on operative time and short-term outcome in laparoscopic cholecystectomy: Experience of an academic Surgical Department in a developing country. J. Minim. Access Surg., 13 (2), 131-134. DOI: https://doi. org/10.4103/0972-9941.186687.

25. Chung, J.H., Kim, T.H., Lee, K.S., Cho, J.M., Kim, K.S., Choi, H.Y., \& Lee, S.W. (2018). The safety and feasibility of the single-port laparoscopic transabdominal preperitoneal inguinal hernia repair through retropubic radical prostatectomy scar, prospective, case series. J. Laparoendosc. Adv. Surg. Tech. A., 28 (12), 1458-1462. DOI: https://doi.org/10.1089/lap.2018.0277.

26. Rami Reddy, S.R., \& Cappell, M.S. (2017). A systematic review of the clinical presentation, diagnosis, and treatment of small bowel obstruction. Curr. Gastroenterol. Rep., 19 (6), 28. DOI: https://doi.org/10.1007/s11894-0170566-9. 


\title{
Огляди літератури, оригінальні дослідження, погляд на проблему, випадок з практики, короткі повідомлення ОЦЕНКА РЕЗУЛЬТАТОВ СИМУЛЬТАННЫХ ЛАПАРОСКОПИЧЕСКИХ АЛЛОГЕРНИОПЛАСТИКИ И ХОЛЕЦИСТЭКТОМИИ
}

\author{
๑Н. М. Галей², И. Я. Дзюбановский', И. П. Марчук²
}

Тернопольский национальный медицинский университет имени И. Я. Горбачевского МОз Украины КП «Волынская областная клиническая больница»

РЕЗЮМЕ. Распространенность калькулезного холецистита и паховой грыжи достигает значительного уровня. Желчнокаменная болезнь поражает до 20 \% взрослого населения мира, а паховая грыжа встречается у 30 \% населения в течение жизни. Сочетание этих патологий не редкость, поэтому методы параллельного лечения актуальны.

Цель - исследовать последствия использования разработанной техники симультанных лапароскопических операций. Оценить результаты лечения желчнокаменной болезни, паховой грыжи и их сочетания. Проанализировать и сравнить основные показатели эффективности и безопасности собственной техники с классическими техниками холецистэктомии и аллогерниопластики.

Материал и методы. С 2013 по 2019 год пролечено 190 пациентов с сочетанной желчнокаменной болезнью и паховой грыжей, из них 19 с двусторонней. Операции выполняли используя собственную технику симультанных операций (группа 1). Также пролечено 312 пациентов с только ЖКБ с использованием стандартной «французской техники» (группа 2) и 237 пациентов с только паховой грыжей, из них 33 с двусторонней, используя стандартную трансабдоминальную преперитонеальную технику (группа 3). Оценка осуществлена путем анализа и сопоставления показателей срока лечения, продолжительности операции, концентрации креатинина сыворотки крови, гликемии, артериального давления. Использовали статистические методы Шапиро -Уилка, критерии Манна -Уитни или U-критерий.

Результаты. Продолжительность операции составила $(58,24 \pm 5,74)$ мин. в первой группе против $(41,8 \pm$ $4,66)$ мин. во второй и $(39,62 \pm 5,13)$ мин. в третьей, и не превышала 2-х часов ни в одной из групп; концентрация креатинина сыворотки крови не превышала допустимые 2 мг/дл ни в одном из случаев и отличалась незначительно ( $p=0,937 / p=0,922)$, нормализовалась в период 6-12 ч; гликемия также не имела различий между группами и возвращалась к норме в срок восстановления перорального питания $(p=0,822 / p=0,954)$ АД удерживалось в пределах нормотонии и разница между интраоперационными показателями в обеих группах была несущественной ( $p=0,912 / p=0,874)$, продолжительность стационарного пребывания не различалась между группами ( $p=0,784 /$ $\mathrm{p}=0,861)$ и составляла 3,55 дня для первой, 3,51 дня для второй и 3,43 дня для третьей групп.

Выводы. Техника, разработанная на базе ОИМДЛ ВОКБ, не уступает по показателям эффективности и безопасности «французской» технике холецистэктомии, и позволяет выполнять симультанное операционное лечение холецистита и паховой грыжи (включая двустороннюю) одномоментно. Использование этой техники является оправданным и целесообразным.

КЛючЕВЫЕ СЛОВА: лапароскопия; симультанные операции; желчнокаменная болезнь; паховая грыжа.

\section{EVALUATION OF THE RESULTS OF SIMULTANEOUS LAPAROSCOPIC ALOHERNIOPLASTY AND CHOLECYSTECTOMY}

\author{
@M. M. Halei², I. Ya. Dziubanovskyi' ${ }^{1}$ I. P. Marchuk ${ }^{2}$ \\ I. Horbachevsky Ternopil National Medical University' \\ Volyn Regional Clinical Hospital
}

SUMMARY. The prevalence of calculous cholecystitis and inguinal hernia reaches significant levels. Gallstone disease affects up to $20 \%$ of the world's adult population, and inguinal hernia occurs in $30 \%$ of the population during lifetime. The combination of these pathologies isn't uncommon, so the methods of parallel treatment are relevant.

The aim - to study the consequences of using the developed technique of simultaneous laparoscopic operations; evaluate the results of treatment of gallstone disease and inguinal hernia and their combination; analyze and compare the main indicators of efficiency and safety of own technique with classical techniques of cholecystectomy and alohernioplasty.

Material and Methods. From 2013 to 2019, 190 patients with combined gallstone disease and inguinal hernia were treated, 19 of them with bilateral. The operations were performed using our own technique of simultaneous operations (group 1). Also, 312 patients with gallstone disease only were treated using standard "French technique" (group 2) and 237 patients with inguinal hernia only, 33 of them with bilateral, using standard transabdominal preperetonial technique (group 3). The assessment was performed by analyzing and comparing the duration of treatment, duration of surgery, serum creatinine concentration, glycemia, blood pressure. Shapiro-Wilk statistical methods, Mann-Whitney criteria or U-test were used. 
Огляди літератури, оригінальні дослідження, погляд на проблему, випадок з практики, короткі повідомлення

Results. The duration of the operation was (58.24 \pm 5.74$)$ minutes in group 1 against (41.8 \pm 4.66$)$ minutes in group 2 and (39.62 \pm 5.13$)$ minutes in group 3, and did not exceed 2 hours in any of the groups; serum creatinine concentration did not exceed the permissible $2 \mathrm{mg} / \mathrm{dl}$ in any of the cases and differed slightly ( $p=0.937 / p=0.922$ ), normalized in the period 6-12 hours; glycemia also had no differences between groups and returned to normal at the time of recovery of oral nutrition ( $p=0.822 / p=0.954)$; AP was kept in notmotonia and the difference between intraoperative parameters in both groups was insignificant $(p=0.912 / p=0.874)$; the length of stay did not differ between groups $(p=0.784 / p=0.861)$ and was 3.55 days for the first and 3.51 for the second and 3.43 for the third group.

Conclusions. The technique developed in Volyn Regional Clinical Hospital is not inferior in efficiency and safety to the "French" technique of cholecystectomy, and allows simultaneous surgical treatment of cholecystitis and inguinal hernia (including bilateral) at the same time. The use of this technique is justified and appropriate.

KEY WORDS: laparoscopy; simultaneous operations; gallstone disease; inguinal hernia.

Отримано 22.10.2020 